\title{
Selection of methods for activated sludge bulking control using a molecular biology technique combined with respirometric tests
}

\author{
ALEKSANDRA MiEOBĘDZKA ${ }^{1,2}$, AdAM MUSZYŃSKi ${ }^{1 *}$ \\ ${ }^{1}$ Faculty of Building Services, Hydro and Environmental Engineering, Warsaw University of Technology, Warszawa, Poland \\ ${ }^{2}$ Department of Molecular Phylogenetics and Evolution, Institute of Botany, University of Warsaw, Warszawa, Poland
}

\begin{abstract}
An excessive proliferation of certain groups of filamentous bacteria results in activated sludge (AS) bulking and foaming. Studies on the efficiency of specific and non-specific methods for AS bulking control were conducted. Polyaluminium compounds (PAX16 and PAX18) were used as specific methods, whereas changes in $\mathrm{pH}$ and in temperature were tested among non-specific methods. Floatation of AS was determined by the Alka-Seltzer-test, ability of AS to settle was measured as sludge volume index. Oxygen uptake rate tests were carried out to determine respiratory activity of AS. Fluorescence in situ hybridisation was applied to identify and quantify filamentous bacteria in AS, which cannot be obtained by the conventional method. Two dominant groups of filamentous bacteria - phylum Chloroflexi and genus Microthrixwere found in AS samples, the latter was the causative agent for bulking. The nonspecific methods for sludge bulking control ( $\mathrm{pH} /$ temperature changes) improved the settling properties, however they did not eliminate filamentous bacteria and in some cases decreased sludge respiratory activity. PAX16 (5.7 mg/kg SS) was the most efficient control strategy for bulking caused by Microthrix-it improved settling properties without increasing tendency to foam and did not decrease respiratory activity of AS.
\end{abstract}

Key words: OUR, FISH, filamentous bacteria, Microthrix, Chloroflexi

\section{Introduction}

Activated sludge (AS) is a consortium of micro- and macro-organisms that is used for wastewater treatment. Typically, it contains about $95 \%$ of bacteria and $5 \%$ of higher organisms such as protozoa, micrometazoa, and lower invertebrates. The AS process relies on the growth of floc-forming bacteria that are able to flocculate and settle down, leaving a clarified supernatant and a thickened sludge to be recycled.

Filamentous bacteria usually constitute more than $25 \%$ of whole bacterial biocenosis in AS (Nielsen et al., 2010; Mielczarek et al., 2012). They serve as a "backbone" for the flocs which are stronger and more resistant to tearing. Filamentous bacteria also adsorb pollutants contained in wastewater, oxidize them, and decompose complex compounds to simpler substances, which can be used as substrates by other bacteria. However, an excessive proliferation of certain groups of filamentous bacteria results in sludge bulking and foaming (Eikelboom, 2000; Jenkins et al., 2004; Wanner et al., 2009). Bulking results in severe operational problems, increasing the treatment costs and lowering the final effluent quality. The most important problem is poor settling of AS which is washed out by the final effluent (Kragelund et al., 2007; Miura et al., 2007; Kragelund et al., 2011). Furthermore, deterioration of the sludge dewatering properties occurs (Eikelboom, 2000).

Two groups of methods can be distinguished for AS bulking control: non-specific methods affecting the whole AS and specific methods which are based on the knowledge about ecophysiology of filamentous bacteria. Strong oxidants, like chlorine or hydrogen peroxide, and

\footnotetext{
* Corresponding author: Faculty of Building Services, Hydro and Environmental Engineering, Warsaw University of Technology, Nowowiejska 20, 00-653 Warszawa, Poland; e-mail: adam.muszynski@is.pw.edu.pl
} 
cavitation destruction of bacterial trichomes are considered as non-specific methods. Specific methods includes identification of operational parameters favorable for the development of specific ecophysiological groups of filamentous bacteria, followed by the elimination of the identified ecotype. For example, filamentous bacteria Candidatus Microthrix parvicella can be eliminated by maintaining a high oxygen concentration and low levels of $\mathrm{NH}_{4}^{+}$in the nitrification tanks, as well as by dosing polyaluminium chloride (PAX). The proliferation of gammaproteobacterial Thiothrix-021N type can be limited by anoxic selectors, introduction of substrate concentration gradients, and removal of sulfides from the wastewater.

Efficient elimination of sludge bulking with specific methods requires proper and reliable identification of filamentous bacteria that are responsible for this phenomenon (Nielsen et al., 2009a). The knowledge of the ecophysiology of microorganisms is crucial to develop a proper strategy for eliminating the particular group of filamentous bacteria. The conventional method of identification to a morphotype (Eikelboom, 2000) does not guarantee the correct classification of the detected filamentous bacteria. Instead molecular techniques are recommended. Recently, the bacterial community structure in activated sludge has most often been studied using fluorescence in situ hybridization (FISH) or sequencing of the 16S rRNA gene (Albertsen et al., 2015; Muszyński et al., 2015; Kaevska et al., 2016).

The methods for AS bulking control are not always successful, especially in cases of incomplete or incorrect identification of filamentous bacteria. Particular groups of filamentous bacteria can proliferate excessively in different situations for different reasons, and efficient control requires knowledge of the mechanisms responsible for these processes. The dominance of a specific group of filamentous bacteria and the reason behind AS bulking can be difficult to explain because of problems in the identification of microorganisms and the influence of technological parameters on quantitative and qualitative changes in AS biocenosis.

In this research, studies on the efficiency of specific and non-specific methods for AS bulking control were conducted. The abundance of dominant filamentous bacteria was determined by FISH. This molecular technique provided useful information about the percentages of specific phylogenetic groups of filamentous bacteria res- ponsible for the operational problems in a full scale wastewater treatment plant, which is not feasible to be obtained by conventional methods of identification to a morphotype. FISH was combined with respirometric tests to reveal the influence of various bulking control methods on sludge activity. These methods were examined in parallel, at the same time and place, to eliminate other factors that could have an effect on the activated sludge properties. The structure of filamentous bacteria population before treatment with the tested methods was compared to the composition of this population after the treatment. The study made a clear distinction of sludge bulking control strategies that target only filamentous bacteria from those influencing the whole activated sludge biocenosis.

\section{Materials and methods}

\section{Sampling}

Samples of bulking AS were collected at the end of October 2014 from the nitrification tank in a wastewater treatment plant (WWTP) in the Masovian province, Poland. Fresh samples were kept in $4^{\circ} \mathrm{C}$ not longer than $24 \mathrm{~h}$ before examination. Samples for FISH analyzes were fixed properly in paraformaldehyde or in ethanol for Gram-negative and Gram-positive bacteria, respectively (Nielsen et al., 2009b).

\section{WWTPS data}

A grab sample of activated sludge was taken from a nitrification tank of a municipal plant with an anaerobic-anoxic-aerobic (A2O) type of reactor. There was also a predenitrification tank and a fermenter; the actual size of the plant was 73400 population equivalents. The WWTP consisted of primary clarifiers, biological N-removal (nitri cation and denitri cation), and well-defined enhanced biological phosphorous removal (EBPR) steps; however, iron-based coagulants (PIX) were used additionally to improve elimination of phosphorus. The nitrification tanks were aerated with a fine bubble diffuser. Severe sludge bulking and poor $\mathrm{N}$ removal (mostly in winter) were documented.

\section{Filamentous bacteria identification}

\section{Identification to morphotype}

Microscopic observations of wet mount preparations, the Gram and Neisser staining, and sulfur deposit 
tests were performed according to Eikelboom (2000) using a Nikon Eclipse 80i microscope. Identification to a morphotype was based on 11 morphological features of the filaments: shape, length, diameter, motility, presence of branching, attached growth of other bacteria to the filaments, (visible or invisible) septa between adjoining cells, shape of the cells, presence of sheath and sulfur granules, according to keys (Eikelboom, 2000; Jenkins et al., 2004).

\section{Fluorescence in situ hybridization}

FISH analyzes were carried out according to Nielsen et al. (2009b). Briefly, activated sludge samples were diluted, homogenized, and then immobilized on standard microscopic multi-well slides to obtain a uniform, homogenous spatial distribution of the biomass. A general EUBmix oligonucleotide probe (equimolar mixture of EUB338, EUB338II, and EUB338III) labeled with 6-Fam was used to target the entire bacterial community. Filamentous bacteria were identified with a selection of nine oligoprobes: CFXmix (equimolar concentration of GNSB-941 and CFX1223 probes, targeting phylum Chloroflexi), MPAmix (equimolar mixture of MPA645, MPA223, and MPA60, targeting Candidatus Microthrix parvicella and Candidatus M. calida), G123T (Thiothrix eikelboomii, T. nivea, T. unzii, T. fructosivorans, T. de uvii, type 021N groups I, II, III), Myc657 (Mycolata), Spin1449 (Skermania piniformis), Gor596 (Gordonia), HHY654 (Haliscomenobacter hydrossis), Curvi997 (types 1701 and 0041/0675 in Curvibacter), and TM7905 (type 0041/0675 in Candidate division TM7). The specific probes were labeled with Cy3. Detailed information about the probes used is provided in probeBase (Loy et al., 2007). Permeabilization steps by enzymatic and chemical treatment with lysozyme $(360000 \mathrm{U} / \mathrm{ml})$, achromopeptidase $(60 \mathrm{U} / \mathrm{ml})$, and hydrochloric acid (1 M) solutions were performed for Gram-positive bacteria only. Hybridization was carried out at elevated temperature $\left(46^{\circ} \mathrm{C}\right)$ within $1.5 \mathrm{~h}$ in hybridization buffers with respective best formamide concentration for each probe to achieve the best quality of probe binding (or overnight hybridization for Gram-positive bacteria). The washing step at a slightly higher temperature $\left(48^{\circ} \mathrm{C}\right)$ was performed to rinse off excess probe molecules and to prevent unspecific binding.

Quantification procedures were accomplished in a manner similar to that described by Miłobędzka and $\mathrm{Mu}-$ szyński (2015). Briefly, digital images for either probe signal were taken in 20 randomly selected fields of view with a Nikon Eclipse 50i microscope. Image J software (Collins, 2007) was used to determine the bio-volume of bacteria which was relative to the pixel area of the cells positive with the specific probe. The microbial abundance (expressed as percentage of EUBmix probe) was then quantified as a percentage of the pixel area for all bacteria positive with the EUBmix probe and was calculated as a mean of 20 separate measurements. The standard error of the mean (SE) was calculated as a standard deviation of the percentage of abundance of the specific bacteria divided by a square root of 20 measurements.

\section{Methods for AS bulking control}

Polyaluminium compounds PAX16 and PAX18 were used as specific methods for AS bulking control (samples No 1-10). Five various doses of two PAX coagulants were tested: $4.5 ; 5.7 ; 7.5 ; 11.8$; and $25.5[\mathrm{mg} / \mathrm{kg}$ suspended solids (SS)], based on the research into bacterial exoenzymatic activity (Nielsen et al., 2005) and the manufacturer's recommendation. Changes in the $\mathrm{pH}$ (sample No 11) and in the temperature were tested among nonspecific methods (Table 1). Research was conducted for $24 \mathrm{~h}$ at room temperature, except samples 13-16 that were incubated at $8^{\circ} \mathrm{C}$ (samples 13,14 ) and $30^{\circ} \mathrm{C}$ (samples 15,16$)$. In all samples $\mathrm{pH}$ was adjusted at 7.2-7.3 (according to the recommendation by Nielsen et al., 2005), except sample 12 which had a $\mathrm{pH}$ that was slightly alkaline, equal to 8.4.

\section{AS characteristics}

Floatation of AS was determined by the Alka-Seltzer ${ }^{\circledR}$ test according to Kopplow and Barjenbruch (2002). Briefly, two Alka-Seltzer ${ }^{\circledR}$ tablets were added to $25 \mathrm{ml}$ of a sample in $500 \mathrm{ml}$ cylinder, the maximum volume of foam was observed and the time from that moment until $50 \%$ of clear water surface was observed was measured.

The ability of AS to settle (sludge volume index - SVI) was measured according to the Polish Standard Method (Mohlmann's index). A well-mixed sludge sample was poured into 11 graduate cylinder and allowed to settle for $30 \mathrm{~min}$. Then the volume of the settled sludge $(\mathrm{ml} / \mathrm{l})$ was recorded and SVI was calculated for SS.

An oxygen uptake rate test (OUR) was carried out according to Kościńska (2005). Briefly, the sludge sample was aerated until saturated with dissolved oxy- 
gen (DO). Then it was added along with acetic acid solution (final concentration $120 \mathrm{mg} \mathrm{COD} / \mathrm{L}$ ) into a bottle with a rubber plug and DO concentration was measured using an optical electrode with $30 \mathrm{~s}$ frequency for 15 min. DO vs. time was plotted for each method of sludge bulking control and compared to the reference plot presenting biomass respiration related to the physiological condition.

\section{Results and discussion}

\section{Identification of filamentous bacteria}

Miłobędzka and Muszyński (2015) showed that three bacterial groups are the most abundant filamentous populations in Polish WWTPs: Chloroflexi, Microthrix, and, to a lesser extent, Skermania piniformis. Chloroflexiare organisms hydrolyzing macromolecules using egzoenzymes. Usually they are hidden inside the flocs and rarely create open-floc structures filled with water, which could result later in operational problems (Nielsen et al., 2010). Bacteria classified to Microthrix morphotype protrude from the flocs, and they are able to build connections, so called "bridging between them". In anoxic conditions Microthrix can store lipids and long-chain fatty acids as lipidic inclusions, which can be used for the growth under aerobic conditions (Nielsen et al. 2010). Therefore, these filamentous bacteria can easily proliferate and cause operational problems (both bulking and foaming) in AS of WWTPs with nutrients removal (Blackall et al., 1989). Skermania piniformis are common, Gram-positive bacteria with a hydrophobic surface, which predestinates them to form stable foam.

The results of FISH analyzes showed two dominant groups of filamentous bacteria in the tested AS samples - phylum Chloroflexi and genus Microthrix (abundance as high as 6 and $12 \%$, respectively), but the latter only was the causative agent for bulking episodes. No positive signals were recorded for Candidate division TM7, Curvibacter, Skermania piniformis, Gordonia, Mycolata, Thiothrix, nor Chloroflexi type 1851. Abundance of each of the three other groups: Chloroflexitype 0803, Chloroflexi type 0092, and Haliscomenobacter hydrossis was smaller than $2 \%$. Therefore for further studies, specific and non-specific methods controlling AS bulking caused by Candidatus Microthrix parvicella (hereinafter called M. parvicella) were tested.

\section{Efficiency of methods for sludge bulking control}

Tests were performed for $24 \mathrm{~h}$, thus the determined efficient method for bulking control concerns the operation in the first day of its use. Efficiency of various methods was evaluated in parallel on the same AS to eliminate the environmental impact and heterogeneity of the samples (Table 1). The best method was selected based on the improvement of settling properties (the lowest SVI), decrease in tendency to foam (the shortest time obtained in the Alka-Seltzer ${ }^{\circledR}$ test), unchanged respiratory activity of AS, and abundance filamentous bacteria after the application of sludge bulking control methods (quantification by FISH).

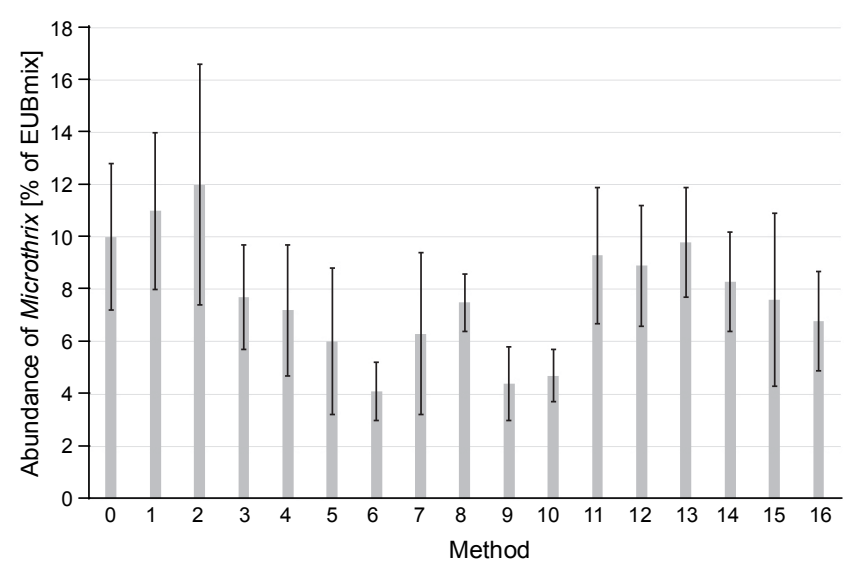

Fig. 1. Abundance of Microthrix in control sample (0) and after treatment with specific and/or non-specific methods (1-16). The error bars illustrate the calculated standard errors

At the beginning of the experiment $M$. parvicella and Chloroflexi accounted for $10 \pm 2.8$ and $5 \pm 1.4 \%$ of all bacteria, respectively. The detailed results of quantification at the end of the experiment (after $24 \mathrm{~h}$ ) are shown in Figure 1. The abundance of $M$. parvicella dropped after treatment with PAX 18 and PAX16 (Table 1, methods No 3-10,12, and 14-16), while the change in $\mathrm{pH}$ and lower temperature did not reduce the Microthrix bio-volume. After treatment with PAX, Microthrix filaments were short and mostly inside the flocs, which makes them not easy to find and to identify by conventional method according to Eikelboom keys (2000), as it was also reported by Paris et al. (2015). Previous studies (Eikelboom, 1997; Roels et al., 2002; Nielsen et al., 2005) reported effective control of $M$. parvicella as well, by addition of polyaluminium compounds in various doses. It was suggested that PAX impairs essential exo- 
Table 1. Efficiency of tested methods for AS bulking control

\begin{tabular}{|c|c|c|c|c|c|c|c|}
\hline $\begin{array}{c}\text { No } \\
\text { of method }\end{array}$ & Type of method & Method & Description & $\begin{array}{c}\mathrm{T} \\
{\left[{ }^{\circ} \mathrm{C}\right]}\end{array}$ & $\begin{array}{c}\text { SVI } \\
{[\mathrm{ml} / \mathrm{g} \mathrm{SS}]}\end{array}$ & $\begin{array}{l}\text { Alka Seltzer }{ }^{\circledR} \text { test } \\
{[\mathrm{s}]}\end{array}$ & $\begin{array}{l}\text { OUR test } \\
\text { - activity }\end{array}$ \\
\hline 0 & - & - & control sample & \multirow{13}{*}{22} & 182 & 52 & normal \\
\hline 1 & \multirow{10}{*}{ specific } & \multirow{5}{*}{ PAX18 } & $4.5 \mathrm{mg} / \mathrm{kg}$ SS PAX18 & & 194 & 3 & normal \\
\hline 2 & & & $5.7 \mathrm{mg} / \mathrm{kg}$ SS PAX18 & & 194 & 2 & normal \\
\hline 3 & & & $7.5 \mathrm{mg} / \mathrm{kg}$ SS PAX18 & & 182 & 22 & normal \\
\hline 4 & & & $11.8 \mathrm{mg} / \mathrm{kg}$ SS PAX18 & & 188 & 12 & normal \\
\hline 5 & & & $25.5 \mathrm{mg} / \mathrm{kg}$ SS PAX18 & & 197 & 4 & normal \\
\hline 6 & & \multirow{5}{*}{ PAX16 } & $4.5 \mathrm{mg} / \mathrm{kg}$ SS PAX16 & & 250 & 0 & normal \\
\hline 7 & & & $5.7 \mathrm{mg} / \mathrm{kg}$ SS PAX16 & & 85 & 0 & normal \\
\hline 8 & & & $7.5 \mathrm{mg} / \mathrm{kg}$ SS PAX 16 & & 265 & 16 & normal \\
\hline 9 & & & $11.8 \mathrm{mg} / \mathrm{kg}$ SS PAX16 & & 218 & 8 & normal \\
\hline 10 & & & $25.5 \mathrm{mg} / \mathrm{kg}$ SS PAX 16 & & 250 & 0 & normal \\
\hline 11 & non-specific & $\mathrm{pH}$ change & $\mathrm{pH} 8.4$ & & 229 & 18 & normal \\
\hline 12 & $\begin{array}{l}\text { combination of non-specific } \\
\text { and specific methods }\end{array}$ & $\mathrm{pH}$ change and PAX 18 & $\mathrm{pH} 8.4+11.8 \mathrm{mg} / \mathrm{kg}$ SS PAX18 & & 256 & 0 & normal \\
\hline 13 & non-specific & temperature change & temperature $8^{\circ} \mathrm{C}$ & \multirow{2}{*}{8} & 244 & 2 & weaker \\
\hline 14 & \multirow{2}{*}{$\begin{array}{l}\text { combination of non-specific } \\
\text { and specific methods }\end{array}$} & \multirow{2}{*}{$\begin{array}{l}\text { temperature change } \\
\text { and PAX } 18\end{array}$} & temperature $8^{\circ} \mathrm{C}+11.8 \mathrm{mg} / \mathrm{kg}$ SS PAX18 & & 165 & 16 & weaker \\
\hline 15 & & & temperature $30^{\circ} \mathrm{C}+11.8 \mathrm{mg} / \mathrm{kg}$ SS PAX18 & \multirow{2}{*}{30} & 124 & 16 & no data \\
\hline 16 & non-specific & temperature change & temperature $30^{\circ} \mathrm{C}$ & & 150 & 24 & no data \\
\hline
\end{tabular}


enzymes in a process of lipids degradation by Microthrix (Andreasen and Nielsen, 2000; Nielsen et al., 2002).

Improvement of the settling ability after $24 \mathrm{~h}$ was observed after dosing PAX16 $(5.7 \mathrm{mg} / \mathrm{kg} \mathrm{SS}$, method No 7$)$, at a higher temperature $\left(30^{\circ} \mathrm{C}\right.$, non-specific method No 16) and changes in temperature combined with PAX18 dosage (methods No 14 and 15). Inhibition of Microthrix growth at high temperatures was also observed in bench scale studies by Mamais et al. (1998), even without limitation of substrate concentrations (oleate and acetate). They reported complete elimination at $29^{\circ} \mathrm{C}$ and stated that high temperatures not only decrease the lipids and fats availability, but also favor other bacteria which outcompete Microthrix. Lienen et al. (2014) also observed that temperature increase can help to control the Microthrix growth, however it must be higher than used in our study (effect proved for $41^{\circ} \mathrm{C}$ ). Similar results, decrease in abundance of $M$. parvicella, were obtained by Marneri et al. (2009) at $55^{\circ} \mathrm{C}$.

The tendency of the tested sludge to foam was reduced by all the methods (Table 1 ). Improvement of sludge settling characteristics and decrease in foaming tendency were previously noticed by Paris et al. (2005) during the aluminum chloride dosing. Also a study by Nielsen et al. (2005) confirmed that a dosage of polyaluminium salts can be an effective control for the growth of Microthrix parvicella in activated sludge and partly explained the mechanism of PAX14 action.

It was shown that the non-specific control measures, like $\mathrm{pH}$ changes and temperature changes, improved the settling properties. However, these methods did not significantly reduce the number of filamentous bacteria (causative agent for bulking), and some of them (methods No 13 and 14 which were based on temperature changes) had a negative effect on the respiratory activity of the whole AS biocenosis, measured by OUR test (Table 1).

PAX16 in dose of $5.7 \mathrm{mg} / \mathrm{kg}$ SS (method No 7) was the best method to eliminate bulking caused by Microthrix. This method decreased bacterial abundance, improved settling properties without increasing tendency to foam, and did not disturb respiratory activity of AS.

\section{Conclusions}

Molecular methods for bacteria identification combined with respiratory tests have been found useful for evaluating the impact of measures for activated sludge bulking control of biochemical activity of microorganisms. The FISH technique made it possible not only to identify filamentous bacteria, but also to determine the percentage of these microorganisms in the tested AS, which could not be obtained by the conventional methods developed by Eikelboom (2000). The research verified opinions on the efficiency of the most popular methods for control of sludge bulking caused by Microthrix. It has been shown that the non-specific methods, like $\mathrm{pH}$ and temperature changes, improved the settling properties. However, these methods did not reduce the number of filamentous bacteria causing bulking. And also, they had a negative effect on the respiratory activity of the AS biocenosis.

The best method that reduced activity of filamentous bacteria from genus Microthrix was dosing the aluminum coagulant PAX16 (5.7 mg/kg SS). It is a specific method which influences only the bacteria from genus Microthrix. It has been shown that the aluminum coagulant did not affect the respiratory activity of sludge neither did it increase the tendency to foam.

\section{Acknowledgments}

This study was financed by the Faculty of Building Services, Hydro and Environmental Engineering of Warsaw University of Technology, grant No. 540M/1110/0022/000.

\section{References}

Albertsen M., Karst S.M., Ziegler A.S., Kirkegaard R.H., Nielsen P.H. (2015) Back to basics - the influence of DNA extraction and primer choice on phylogenetic analysis of activated sludge communities. PLoS ONE 10(7): e0132783.

Andreasen K., Nielsen P.H. (2000) Growth of Microthrix parvicella in nutrient removal activated sludge plants: Studies of in situ physiology. Water Res. 34: 1559-1569.

Blackall L.L., Parlett J.H., Hayward A.C., Minnikin D.E., Greenfield P.F., Harbers A.E. (1989) Nocardia pinensis sp.nov. an actinomycete found in activated sludge foams in Australia. J. Gen. Microbiol. 135: 1547-1558.

Collins T.J. (2007) ImageJ for microscopy. Biotechniques 43: 25-30.

Eikelboom D.H. (1997) Control by Microthrix parvicella by addition of $P A X-14$. TNO-MEP- R97/305. Appeldoorn: TNO Institute of Environmental Sciences, Energy Research and Process Innovation.

Eikelboom D.H. (2000) Process control of activated sludge plants by microscopic investigation. London: IWA Publishing.

Jenkins D., Daigger G., Richard M. (2004) Manual on the causes and control of activated sludge bulking, foaming and other solids separation problems. London: IWA Publishing. 
Kaevska M., Videnska P., Vasickova P. (2016) Changes in microbial composition of wastewater during treatment in a full-scale plant. Curr. Microbiol. 72: 128-132.

Kopplow O., Barjenbruch M. (2002) Beurteilung und Weiterentwicklung von Methoden zur Erfassung des Schaumpotentials (Evaluation and development of methods for determination of foam potential). Universität Rostock: Abschlussbericht AZ 1199, Institut für Kulturtechnik und Siedlungswasserwirtschaft.

Kościńska K. (2005) Testy biochemiczne jako narzędzie oceny procesów biologicznego oczyszczania ścieków. Ochr. Środ. Zasob. Natural. 28: 25-40.

Kragelund C., Remesova Z., Nielsen J.L., Thomsen T.R., Eales K., Seviour R., Wanner J. Nielsen P.H. (2007) Identity, abundance and ecophysiology of filamentous Chloroflexi species present in activated sludge treatment plants. FEMS Microbiol. Ecol. 59: 671-682.

Kragelund C., Thomsen T.R., Mielczarek A.T., Nielsen P.H. (2011) Eikelboom's morphotype 0803 in activated sludge belongs to the genus Caldilinea in the phylum Chloroflexi. FEMS Microbiol. Ecol. 76: 451-462.

Loy A., Maixner F., Wagner M., Horn M. (2007) ProbeBase an online resource for $r$ NA-targeted oligonucleotide probes: new features 2007. Nucl. Acids Res. 35: D800-D804.

Marneri M., Mamais D., Koutsiouki E. (2009) Microthrix parvicella and Gordonia amarae in mesophilic and thermophilic anaerobic digestion systems. Environ. Technol. 30(5): 437-444.

Mamais D., Andreadakis A., Noutsopoulos C., Kalergis C. (1998) Causes of, and control strategies for Microthrix parvicella bulking and foaming in nutrient removal activated sludge systems. Wat. Sci. Technol. 37: 9-17.

Mielczarek A., Kragelund C., Eriksen P.S., Nielsen P.H. (2012) Population dynamics of filamentous bacteria in Da nish wastewater treatment plants with nutrient removal. Water Res. 46: 3781-3795.

Miłobędzka A., Muszyński A. (2015) Population dynamics of filamentous bacteria identified in polish full-scale wastewater treatment plants with nutrients removal. Wat. Sci. Technol. 71(5): 675-684.
Miura Y., Watanabe Y., Okabe S. (2007) Significance of Chloroflexi in performance of submerged membrane bioreactors (MBR) treating municipal wastewater. Environ. Sci. Technol. 41(22): 7787-7794.

Muszyński A., Tabernacka A., Miłobędzka A. (2015) Longterm dynamics of the microbial community in a full-scale wastewater treatment plant. Int. Biodeter. Biodegr. 100: 44-51.

Nielsen P.H., Roslev P., Dueholm T.E., Nielsen J.L. (2002) Microthix parvicella, a specialized lipid consumer in anaerobic-aerobic activated sludge plants. Wat. Sci. Technol. 46: 73-80.

Nielsen P.H., Kragelund C., Nielsen J.L., Tiro S., Lebek M., Rosenwinkel K.H., Gessesse A. (2005) Control of microthrix parvicella in activated sludge plants by dosage of Polyaluminium salts: possible mechanisms. Acta Hydroch. Hydrob. 33(3): 255-261.

Nielsen P.H., Kragelund C., Seviour R.J., Nielsen J.L. (2009a) Identity and ecophysiology of filamentous bacteria in activated sludge. FEMS Microbiol. Rev. 33: 969-998.

Nielsen P.H., Daims H., Lemmer H. (2009b) FISH Handbook for Biological Wastewater Treatment. London: IWA Publishing.

Nielsen P.H., Mielczarek A.T., Kragelund C., Nielsen J.L., Saunders A.M., Kong Y., Hansen A.A., Vollertsen J. (2010) A conceptual ecosystem model of microbial communities in enhanced biological phosphorus removal plants. Water Res. 44: 5070-5088.

Paris S., Lind G., Lemmer H., Wilderer P.A. (2005) Dosing aluminum chloride to control Microthrix parvicella. Acta Hydrochim. Hydrobiol. 33(3): 247-254.

Roels T., Dauwe F., Van Damme S., De Wilde K., Roelandt F. (2002) The influence of PAX-14 on activated sludge systems and in particular on Microthrix parvicella. Wat. Sci. Technol. 46: 487-490.

Wanner J., Kragelund C., Nielsen P.H. (2009) Microbiology of bulking. [in:] Microbial ecology of activated sludge. Ed. Seviour R.J., Nielsen P.H., London: IWA Publishing: 191214. 